Relations industrielles

Industrial Relations

\title{
Steven L. Willborn, A Secretary and a Cook. Challenging Women's Wages in the Courts of the United States and Britain
}

\section{Nancy Sullivan}

Volume 46, numéro 1, 1991

URI : https://id.erudit.org/iderudit/050655ar

DOI : https://doi.org/10.7202/050655ar

Aller au sommaire du numéro

Éditeur(s)

Département des relations industrielles de l'Université Laval

ISSN

0034-379X (imprimé)

1703-8138 (numérique)

Découvrir la revue

Citer ce compte rendu

Sullivan, N. (1991). Compte rendu de [Steven L. Willborn, A Secretary and a

Cook. Challenging Women's Wages in the Courts of the United States and

Britain]. Relations industrielles / Industrial Relations, 46(1), 226-228.

https://doi.org/10.7202/050655ar

Tous droits réservés @ C Département des relations industrielles de l'Université Laval, 1991
Ce document est protégé par la loi sur le droit d'auteur. L'utilisation des services d'Érudit (y compris la reproduction) est assujettie à sa politique d'utilisation que vous pouvez consulter en ligne.

https://apropos.erudit.org/fr/usagers/politique-dutilisation/ 
Joyce Jacobson provides a neoclassical economic critique of comparable worth, highlighting that even if many of the unrealistic assumptions of the competitive model are dropped, comparable worth leads to inefficiencies and adverse employment effects. She also argues that it does not receive high grades as a policy to achieve equity or fairness, in part because such concepts are often illdefined.

Elaine Sorensen provides a critical review of the theoretical and empirical literature on the relationship between the sex composition of an occupation and wages - and ultimately the male-female wage gap. She highlights the problems with the data and empirical procedures used in most studies and provides some new evidence that takes account of many of these problems. She finds that the pay in jobs held exclusively by women tends to be 23 percent less than the pay in jobs held exclusively by men, even after controlling for productivity-related and industrial differences. This importance of occupational segregation as a determinant of the male-female earnings gap, highlights the substantial potential for comparable worth legislation to reduce that gap.

In the final paper, Ron Ehrenberg reviews the empirical procedures and evidence on the impact of comparable worth, especially on wages and employment. His assessment of the evidence is that comparable worth would have only a modest effect on reducing the overall male-female earnings gap, and it would also have only a small adverse employment effect on females.

Each of the papers were enriched by comments and clarifications from discussants, who also often added new material of their own. The editors also provided a concise summary as well as some background material.

While the volume makes an important contribution to the literature, it has a number of shortcomings. First, it could have benefited by a discussion of a number of the implementation and design issues pertaining to such factors as estimating pay lines, adjusting wages, defining the establishment, defining the role of collective bargaining, and allowing exemptions. Second, given the timeliness of the topic, a shorter gap between the conference in 1987 and the publication of the volume in 1989 would have been desirable. Third, the volume would have benefitted by a discussion of Canadian initiatives in this area, given their importance in recent years. We wont claim overt discrimination because our policy initiatives were excluded - just unintended systemic discrimination! Fortunately, these shortcomings are vastly outweighed by the strengths of the book.

Morley GUNDERSON

University of Toronto

\section{A Secretary and a Cook. Challenging Women's Wages in the Courts of the United States and Britain, by Steven L. WILlBORN, Ithaca, ILR Press, 1989, 214 p., ISBN 0-87546-158-1}

This is the author's second book on the issue of comparable worth or pay equity as it is known in Canada. Willborn's 1986 A Comparable Worth Primer looked at the principle from three different angles - economics, litigation and legislation. This new work provides a detailed comparative study and analysis of two seminal court cases. The author's stated intention is to extrapolate general principles from a microscopic examination of the cases, and in this he succeeds admirably.

The reader will have no doubts about Prof. Willborn's position as an advocate of comparable worth. His strong support for the two complainants, Helen Castrilli, a secretary employed by the State of Washington, and Julia Hayward, the cook of the title, employed by a 
British shipbuilding firm, is obvious throughout the book. His discomfort with the quality of many of the legal decisions made by the courts and arguments presented by legal counsel in both countries is also clear.

The first part of the book consists of an in-depth examination of two lawsuits, one launched in Britain against a private sector employer; the other in the United States against a public sector employer. This section alternates, chapter by chapter, between developments in the Castrilli case which began in July of 1982 and the Hayward case, the first complaint filed under the amended Equal Pay Regulations in Britain in 1984.

The author succeeds in making complex compensation and legal arguments understandable by personalizing the cases through detailed descriptions of the worksites, the employees who worked there and the jobs they performed. Rather than presenting a dry legal tome, he has concentrated on the human elements of the cases and the determination of two women on opposite sides of the Atlantic to keep up their fight until they received what each considered to be fair compensation for the work they performed.

Throughout the highly readable examination of the courtroom and backroom drama surrounding both cases, Prof. Willborn draws out differences and similarities in the nondiscrimination legislation, legal process and social climates in each country.

Neither Castrilli nor Hayward's fight ended when a lower court and an industrial tribunal respectively, ruled that both employers had discriminated in their pay practices against women working in female-dominated occupations.

The State of Washington appealed the lower court decision to a higher court and there the decision was reversed. Despite this, in 1986, the union representing Ms. Castrilli and other secretaries working for the State, reached a without prejudice settlement to provide $\$ 101$ million over seven fiscal years to bring all occupations to within two ranges of an average actual comparable worth salary line. Willborn describes the end result in this landmark comparable worth case as "... a tattered brown paper bag, but inside there was a pleasant little gift." Ms. Castrilli and other state employees received salary increases, but the appeal court decision "would stand for the proposition that comparable worth cases could not be won in the United States".

Julia Hayward, on the other side of the Atlantic, succeeded in winning the legal argument, but was forced to ultimately go to the House of Lords for a decision on whether her legal victory entitled her to a salary increase. The employer and the union in this case could not agree on what constituted total compensation and how benefits were to be costed. In Chapter 8 Willborn provides a summary of the arguments on both sides of this issue which is still a topic of dispute in the many Canadian provinces where pay equity legislation is being implemented. Ms. Hayward finally succeeded in having her salary raised in 1988.

The lessons to be derived from these two cases are set out in Part 2 of the book where the author analyzes the theory, promise and limits of comparable worth. Human resource practitioners and comparable worth advocates and students will wish that Willborn had devoted more space to this "consideration of the general theory of comparable worth and for an evaluation of the promise and limitations of comparable worth in practice."

Willborn's basic premise is that "the theory of comparable worth must begin... not with job comparison but with the antidiscrimination principle." That is, that sex discrimination, not job comparison was the key issue in both cases. 
Part 2 of the book examines nondiscrimination legislation in both countries. The author's technique is effective. Much like a lawyer presenting a case in court, he puts forward a reasoned argument for not holding employers directly responsible for discrimination in comparable worth cases since they are simply following the general wage practices in their industry. He then tears down this defense and argues that comparable worth must be treated in the same way as any other form of discrimination i.e. that there does not have to be a deliberate intent to discriminate in order for a practice to be discriminatory.

Chapter 10 examines the wage gap between men and women workers and the literature that exists on what portion of this wage gap is attributable to the undervaluation of "women's work". The author argues that the goal of narrowing the wage gap is a by-product of the central goal of comparable worth - " "... eliminating discrimination based on the sex composition of occupations".

Comparable worth in Willborn's view, is a legal doctrine analogous to the commitment to racial equality and worth pursuing as "an important societal ideal and value".

The final chapter examines the practical difficulties of applying the theory of comparable worth and, the efficacy of attempting to achieve the end goal through the courts.

The book ends with a sound analysis of the difficulties surrounding reliance on job evaluation as evidence of sex-based wage discrimination in the courts. In both countries, the reliability of job evaluation was raised as a major issue in the legal arguments. Ultimately Willborn argues that this is a red herring and notes that "All cases in litigation - not just comparable worth cases - are decided on the basis of incomplete information and in the face of uncertainty."

The author concludes that, as with many other public policy issues, litigation alone is unlikely to have a direct impact on the overall wage gap between men and women workers. The costs of court challenges are extremely high and in the British case, the decision applied only to the complainant, since the legislation does not permit class action claims. Litigation, Willborn argues, should be seen as only one of the initiatives that can be used to achieve the central goal of comparable worth - eliminating or reducing discrimination based on the sex composition of occupations.

"Litigation provides a rifle that can target instances of this type of discrimination that might be missed by the shotgun approach of the other initiatives... litigation provides a forum for making important statements of public values and societal ideals."

Above all, the book raises the need for approaches other than litigation, which is timeconsuming and expensive, to deal with the undervaluation of female-dominated occupations.

Besides providing readers with a thorough comparative analysis of legal practices and policies in two very different judicial systems, Willborn has given us an added bonus - the book is a good read!

This will be a useful text for students in a wide variety of disciplines - law, economics, and human resource management.

Nancy SULLIVAN

Manitoba Department of Labour 